\title{
Environmental Pollution, Its Health Implications and Diseases Associated with Waste and Their Mode of Transmission.
}

\author{
${ }^{1}$ Ogodo, A.D, ${ }^{2}$ Idehen, Q.O., ${ }^{3}$ Egere, U.G. \& ${ }^{4}$ Akpofure, I.H. \\ ${ }_{1}^{1}$ Deptt of Science Laboratory Techn, Delta State Polytechnic, Ogwashi-Uku, Nigeria. \\ ${ }^{284}$ Industrial Safety and Environmental Techy Dept (ISET), Petroleum Training Institute (P.T.I.), Effurun, Nigeria. \\ ${ }_{3}^{3}$ Petroleum and Natural Gas Processing Department (PNGP), Petroleum Training Institute (P.T.I.), Effurun, Nigeria.
}

\begin{abstract}
Environmental pollution has become topical worldwide so much so that no day passes without the issue being discussed somewhere in the world especially the state of Human health in the Niger Delta Region of Nigeria. This research work shows that man is largely responsible for pollution of the air, the sea and the land and this pollution posed the greatest danger to the atmosphere. This research shows the criminal nature of pollution of the environment. The research $\mathrm{x}$-rays some of the causes of Environmental degradation; its health implications and diseases associated with wastes and their mode of Transmission. The research emphasizes on some waste management practical facts and regulations that need Constitutional Reforms, Historical Progression of Environmental Laws in Nigeria, Environmental Courts, Ineffective Enforcement of Environmental Laws, Health Impact Assessment Studies, Pollution and Its Health Implications, Prevention and Control/Management of Wastes. Finally, the research work concluded with some recommendations as we strive to live in a healthy environment to avoid all forms of environmental pollution and diseases. The research work concluded that Environmental Pollution is all about GLOOM, NO GLEE.
\end{abstract}

Keywords: Environmental Pollution (ALL GLOOM, NO GLEE), Health Implications, Human Diseases and Mode of Transmission, Environmental Courts (Legal Enforcement of Environmental Laws), Health Impact Assessment Studies.

Proceedings Reference Format

Ogodo, A.D, Idehen, Q.O., Egere, U.G. \& Akpofure, I.H. (2021 Environmental Pollution, Its Health Implications and Diseases Associated with Waste

and Their Mode of Transmission... Proceedings of the 27th iSTEAMS Multidisciplinary Innovations \& Technology Transfer (MINTT) Conference. Academic City University College, Accra, Ghana. June, 2021. Pp 201-220 www.isteams.net/ghana2021. DOI - https://doi.org/ 10.22624/AIMS/iSTEAMS-2021/V27P17

\section{INTRODUCTION}

The term "Environment" consists broadly of the following, namely;

(a) The Physical environment, which consists of the atmosphere (air), soil, water, surface topography and climate.

(b) The Biological environment, which comprises of living things such as plants, animals and microorganisms.

(c) The Socio-Economic environment, which comprises of the culture, commerce, urbanization, family, organization of society, government, law and judicial process ${ }^{(1)}$. 


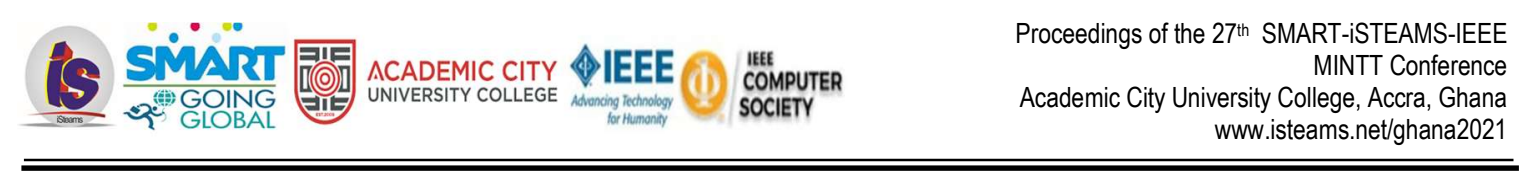

Environmental pollution has become topical worldwide, so much so, that no day passes without the issue being discussed somewhere in the world(2). The state of affairs in the Niger Delta region on global environmental pollution will be highlighted being the largest Delta in Africa and containing the third largest mangrove forest in the world. The Niger Delta is indeed of great interest to Environmentalists and industrialists both locally and internationally, because of its rich potentials in fisheries, agriculture and of course, Oil and gas ${ }^{(3)}$. The Niger Delta basin is situated on the continental margin of the Gulf of Guinea in equatorial West Africa(4).

\section{Historical Progression of Environmental Laws in Nigeria}

Environmental law is therefore intended to retard, hopefully to correct, the adverse effects of human activities upon the natural environment and its resources, with primary intent to curtail detrimental uses of property. Hence, (5) has opined that there should be a general and comprehensive environmental legislation for a continuous assessment and monitoring of the environment and its resources including air, water, land, animal and plant life.

The earliest effort of Nigeria government in environmental protection legislation was geared towards public health and safety and conservation and protection of economically important natural resources:

1. Public Health Act 1958.

2. Destructions of Mosquitoes Act 1958.

3. Forestry Act 1958.

4. Minerals Act 1958.

5. Mineral Oils Safety Regulations 1963.

6. Oil in Navigable Water Act 1968.

7. There were no laws at the beginning of industrial pollution, and hazardous wastes managements.

\section{Ineffective Enforcement of Environmental Laws}

It beats me, that with so many Environmental Protection Bodies in Delta State like the Federal Environmental Protection Agency (FEPA) now Federal Ministry of Environment, Delta State Environmental Protection Agency (DELSEPA), Department of Petroleum Resources (DPR), the quality of our environment is still being tortured by the unfriendly use by industries in Warri. Could it be that these agencies do not have enough manpower to enforce these laws? I think that stringent penalties have to be melted to industries that are defaulters of our natural environment. The environmental objective of sustainable industrial development include the sound management of natural resources, effective transfer of environmentally sound technologies in order to reduce, reuse, recycle waste, investment promotion for sustainable industries and environmental industry projects ${ }^{(6)}$.

\section{HOUSE OF REPRESENTATIVES, STAKEHOLDERS HOLD INDUSTRIES, FIRMS RESPONSIBLE FOR POOR SOLID WASTE MANAGEMENT}

The House of Representatives and other Stakeholders have agreed that industries and other commercial enterprises in the Country should be held responsible for the disposal of the solid wastes generated as a result of their operations. This revelation was taken during a recent Stakeholders' meeting on Promoting a Healthy and Friendly Environment Through Disposing Industrial Wastes. The Speaker of the House, Rt. Hon. Aminu Tambuwal, while declaring the session open, enjoined manufacturers and distributors in the country to implement the Extended Producer Responsibility (EPR) Programme which was to safeguard the environment against the harmful effects of industrial waste ${ }^{(7)}$. 


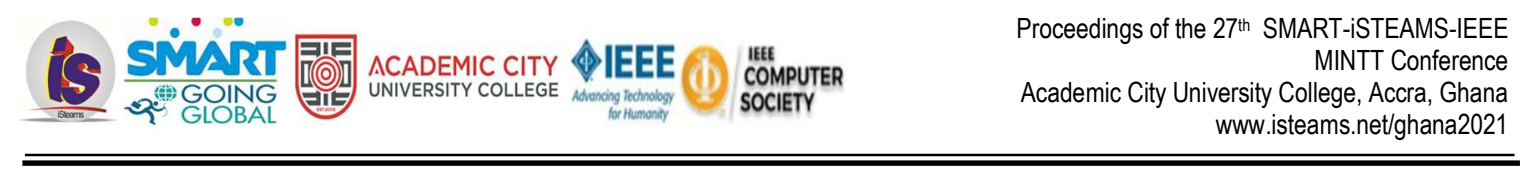

He explained that the concept required that product manufacturers had a responsibility of monitoring their life cycle from the factory to the point of recovery of the end waste. The Speaker who was represented by a PDP lawmaker from Akwa Ibom State, Mr. Akpan Micah-Umoh, added, "All over the world, Countries have realized the need to make Companies responsible for the waste they generate. Nigeria should not be an exception.

The Chairman, House Committee on Environment, Mrs. Uche Ekwunife, expressed worries that industries in Nigeria cared less about how the waste generated by their products was disposed of eventually. She noted that a common practice in the Country was for consumers to litter the environment with waste after using industrial products. According to her, "what we are doing here today is about who has the responsibility for managing the waste we generate as a people". "For instance, a can of Malt drink was produced by a Company, bought by a retailer and then sold to the end user. Now, whose responsibility is it to safely manage this waste? We believe it is a tripartite thing. So, we want all the Stakeholders to know their stake before enforcement agencies can go into full action".

However, the Permanent Secretary, Ministry of Environment, Mrs. Rabi Jimeta, claimed that attempts to implement the Extended Producer Responsibility (EPR) were often frustrated by commercial concerns, whose owners were unwilling to support the idea. "Unfortunately, the compliance to this programme has been very weak despite several efforts by the National Environmental Safety Regulatory and Enforcement Agency. We must ensure that we do all businesses in an environmentally-friendly manner(7).

"There is need to put in place instructive legal framework for this programme, which is where the role of the House Committee on Environment becomes very important with regards to enforcement". NESREA's DirectorGeneral, Dr. Ngeri Benebo, told the session that the agency had held several discussions with food and beverage companies with a view to implementing the Extended Producer Responsibility (EPR). The DG solicited the backing of the House to carry out a successful implementation of the Extended Producer Responsibility (EPR). However, an environmental expert, Professor Oladele Osibanjo, said the buck still stopped on the table of government to lead the way. He warned that the country could face serious danger if it continued to pay lip service to the implementation of the EPR. According to Professor Osibanjo: "About 50 million metric tonnes of e-waste, which contain precious metals such as gold and silver capable of generating more employment if adequately harnessed, are produced annually"(7).

\section{ENVIRONMENTAL COURTS}

A court is an institution for settlement of disputes. Some courts are specialized because of the technical nature of the matter for which they were created. Some States believe that the question of environmental enforcement is not amenable to the normal courts and so they created a special court with special powers to enforce breaches or environmental laws. For example, the Rivers and Cross River Edicts created a Tribunal and a Court respectively. Lagos State jurisdiction on environmental cases is conferred on the magistrate and customary court. The State uses established Courts and did not actually create an environmental court. Section 22 of the sanitation law thus enlarged the jurisdiction of the Magistrate and Customary Courts of the State ${ }^{(8)}$. This was perhaps based on the assumption that the offenders are likely to be drawn from masses. By virtue of this provision, Companies can appear before a customary court for offences against the environment and individuals for not mindful of their neighbours in their pollution spree or for discharging refuse or sewage effluents into the streets. In most cases nowadays, mobile courts are now established for trying environmental offenders. 


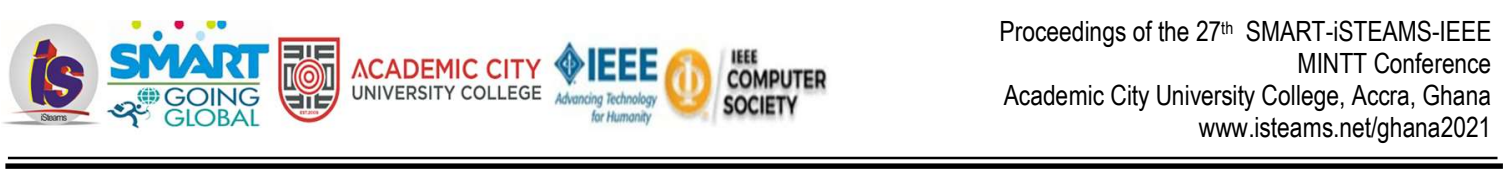

\section{Legal Issues Raised}

1. The Government of Nigeria has promulgated a fair collection of Federal, State and Local Government Legislation on waste management.

2. Government's implementing agencies and the public largely ignore these laws.

3. The responsibility for waste management lies with so many government agencies at all levels that it is easy to pass the buck without achieving anything.

\section{Harmful Waste (Special Criminal Provisions, Etc) Act Cap. 165 L.F.N. 1990}

The Act prohibits the carrying, depositing and dumping of harmful waste on any land, territorial waters and matters relating thereto. Its definition of "harmful waste" in Section 15 clearly would include some petrochemical wastes, which may be "injurious, poisonous, toxic or noxious...." This law is certainly significant as a breach of its provisions invokes criminal and civil liabilities.

Section 1 prohibits and declares unlawful all activities relating to the purchase, sale, importation, transit, transportation, deposit, and storage of harmful wastes. Section 1(2) declares that any person who, without authority -

- Carries, deposits, dumps or causes to be carried, deposited or dumped. Or is in possession for the purpose of carrying, depositing or dumping any harmful waste on any land or in any territorial waters or contiguous zone or Exclusive Economic Zone of Nigeria or its Inland waterways; or

- Transport or causes to be transported or is in possession for the purposes of transporting any harmful waste; or imports or causes to be imported or negotiates for the purpose of importing any harmful waste; or sells, offers for sale, buys, or otherwise deals in any harmful waste, shall be guilty of crime under this Act.

\section{Some Waste Management Practical Facts and Regulations That Need Constitutional Reforms}

It is expected that houses, business premises, eateries, drinking parlours, abattoirs, shops and factories are to be inspected regularly by the State sanitation Authority. You are to provide waste disposal bins as well as pay the services of waste collection agents who will be regulated by the government (Delta State Refuse Collection and Disposal Edict). Every householder, landlord or caretaker is responsible for the sanitation and hygiene of his house or premises; and shall provide a refuse bin of galvanized or other metal or plastic with a lid measuring $50,000 \mathrm{~cm}$ in capacity (Delta State Refuse Collection and Disposal Edict). All food edibles are to be analyzed in a state maintained laboratory before they go into the market place. Any noxious matter or water that flows out onto streets is a nuisance according to law (Public Health Laws Cap 103 of 1963). Accumulation of rubbish of any kind, whether of animal or plant origin or of any type of refuse is also declared a nuisance by law (Public Health Laws Cap 103 of 1963). Solid waste generated by any industry or facility, including sludge and all byproducts, resulting from the operation of pollution abatement equipment, shall be disposed of in an environmentally safe manner. No industrial solid waste shall be disposed of in any municipal landfill.

\section{Pollution and its Health Implications}

Experts have warned on adverse health implications on the burning of refuse in landfill site under prevailing weather conditions around our environment including Sapele, Effurun, Ekpan, Warri and Orerokpe in Delta State. The dangers they pose include such upper respiratory infections as pharyngitis, laryngitis and cough as well as lower respiratory infections like asthma, tuberculosis and measles. The wind flow charts have been at upper level, the dust haze has caused inhibition of visibility as well as early morning fog and mist. 


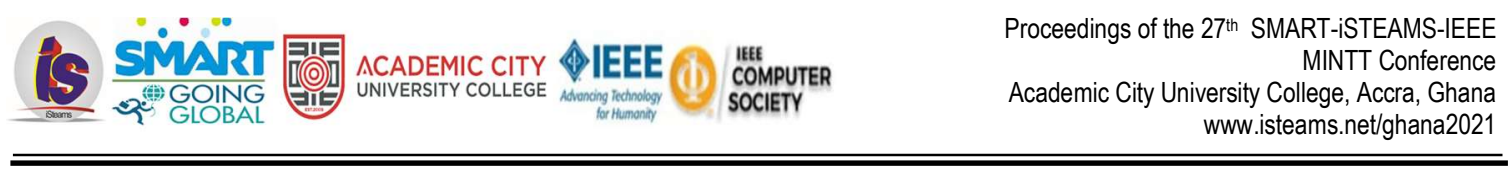

Besides, thick smoke continues to emanate from burning dumpsites in our environment. Medical experts disclose that the smoke combined with the fog and mists, which are associated with Harmattan, has been blamed on health-related problems and poor visibility among motorists.

\section{Sewage}

Most septic tanks, soakaways and latrines are not well covered and vectors of diseases find their way in and out of them thus transmitting diseases in the environment. When sewage and faeces are passed in the open environment, water body, bush or into refuse, they contaminate and pollute the environment and are exposed to vectors that transmit disease-causing parasites and pathogens to people. There are so many diseases due to poor sanitation and sanitary habits and poor management of sewage and faeces. Usage of faeces and sewage as agricultural manures and fertilizers coupled with general poor personal hygiene can result in several faeco-orally transmitted diseases associated with poor sewage and refuse disposal. They are Cholera, Typhoid, Amoebic, Dysentery, Ascariasis Fascioliasis, Homeward diseases, Schistosomiasis (Bilharzia), Tapeworm infections, Whipworm infection ${ }^{(9)}$. Presence of this in abundance is also due to poor sanitation in the environment and this encourages diseases like Malaria, Trypanosomiasis, Leishmaniasis, Filariasis e.g. Orchocerciasis, Elephantissis, Loasis ${ }^{(12)}$.

\section{Commercial Wastes}

It is certain that most commercial wastes add to the huge refuse dumps seen in the environment and cause diseases similar to those refuse dumps. Commercial waste items like cellophane bags, plastics, cartons, back drains and gutters help to retain water where mosquitoes and some pathogens breed. Blocked drain also contributes to flooding in cities. A lot of uncompleted commercial projects like houses and roads with ditches, abandoned vehicles and containers serve as refuse and sewage dumps and help to retain where flied, mosquitoes and pathogens breed and carried by vectors to people in the environment.

\section{Agricultural Wastes}

Most agricultural wastes add to the refuse dump seen in the municipal and cause diseases similar to those of refuse dumps. Agricultural chemicals like fertilizers, pesticides leach into the groundwater thereby polluting groundwater with excess Chlorine, Nitrate, Heavy metals, Hydrocarbons etc, and can cause bioaccumulation of these chemicals in people that use such groundwater. During food processing, improper handling of food can result in food poisoning, food spoilage and food waste. Such waste when disposed can cause added pollution and consummation causing various diseases in the environment.

\section{Industrial Wastes}

Industrial accidents e.g. Oil spillage due to pipe vandalization and accidents can be a major hazard, destroying life, biotic and abiotic components of the environment and causing a number of respiratory skin and internal diseases. Apart from accidents and occasional deaths resulting from poor management in industries, effluents from industries are of various types and degrees and cause various forms of pollution and contamination in the environment. Chemical pollution in form of bombs at wartime can be disastrous and the inherent diseases last for a very long time. Examples of some diseases due to industrial pollution are given in Tables 2, 3 and 4 . Some produce heated water, poisonous and liquids and chemicals by-products that are passed into the environment or into water bodies causing pollution and contamination resulting in various diseases of the skin and of the respiratory system. Some of these by-products can kill vegetation and other biotic components of the environments(4). 


\section{HEALTH IMPACT ASSESSMENT STUDIES}

Industrialization if not properly managed causes a lot of harm to human health, e.g. causing Air, Water and Land pollution, which invariably is a huge threat to man, because the ecological base for natural resources would be depleted and degraded, for example, aquatic life which is a cheap source of protein can be disturbed if untreated. Industrial waste is indiscriminately discharged into rivers, especially when its load demands a lot of Oxygen for it to break down. Also, other effects on human beings is that, it can cause cancer, asthma, birth defects( $(6)$.

Health Impact Assessment (HIA) is a measure used in assessing health risk associated with developmental projects. In order to evaluate the health risk resulting from development industries, studies and surveys were conducted to ascertain these effects. It is sad to note that the result of the Health Impact Assessment (EIA) records form hospitals shows that there is no statistical data showing the health risk between industrial pollution incidents in the study area yet health effect has been pronounced in the Oil active areas which are Effurun, Ekpan, Enerhen, Ughelli, Uzere, Sapele, Orerokpe etc.

Respondent who is questioned linked the various health problems present in their Communities to the activities of Oil prospecting/allied industries. Some of the prevalent health effects attributed to the activities include:

- $\quad$ Persistent headache.

- $\quad$ Eye and ear problems.

- $\quad$ Pregnancy disorder.

- $\quad$ Respiratory disorder - Flu, Asthma, Cough etc.

Medical research study has to come in to find out whether these health problems highlighted are traced to their Companies so that a proper measure is employed to cure the people suffering in these Communities ${ }^{(6)}$. One of the dilemmas of our time is that man has not been able to keep the air he breathes or the water he drinks pure enough, or the land on which he has his shelter or farms to obtain his food clean enough to sustain life and good health (10).

Nature, for example, is responsible for the dispersal of pollen, micro-organisms and insects, or parts of insects, such as hairs, wings or legs. These particles have deleterious effects on man causing hay fever, bronchial asthma, various fungous infections and air born bacteria diseases ${ }^{(2)}$. Aluminium in our drinking water can cause a condition known as Alzheimer's disease. This disease makes people age morerapidly, resulting in some loss of memory at a much younger age than normal(11).

\section{Diseases Associated With Waste and Their Mode of Transmission}

Refuse: It is usually visited by various animals (e.g. dogs, chicken, flies, rats) and vector of diseases because it contains lots of organic remain which these animals use for their food. Also, it is a good breeding ground for flies and various disease pathogens hence flies and other vectors can transfer disease causing parasites and pathogens from refuse to other parts of the environment. When faeces, urine and dead animals, washed organic matter are passed into refuse, it then serves as a breeding ground where parasites and pathogens that cause various diseases can be contacted. Irritating smell of refuse can affect and choke asthmatic and allergic patients and renders the environment unpleasant. Some biological agents of Humans Diseases associated with refuse polluted air, land, and water are as stated in Table 1. 
Table 1: Human Diseases Associated with Refuse, Sewage and Polluted Water.

\begin{tabular}{|c|c|c|c|}
\hline $\begin{array}{l}\text { Types of } \\
\text { Organisms }\end{array}$ & Agent & Disease & Mode of Transmission \\
\hline Bacteria & $\begin{array}{l}\text { Vibrio Cholera Salmonella } \\
\text { Typhi } \\
\text { Other Salmonella sp } \\
\text { E.coli of Pathogenic types } \\
\text { Shigella Dysentariae } \\
\text { Legionella sp. }\end{array}$ & $\begin{array}{l}\text { Cholera } \\
\text { Typhoid } \\
\text { Enteritis (intestinal } \\
\text { inflammation) } \\
\text { Enteritis } \\
\text { Dysentery } \\
\text { Pneumonia/like pulmonary } \\
\text { disease. }\end{array}$ & $\begin{array}{l}\text { Direct contact of } \\
\text { infective stage or } \\
\text { through vector. } \\
\text { " } \\
\text { " } \\
\text { " }\end{array}$ \\
\hline Protozoans & $\begin{array}{l}\text { Entamoeba histolytica } \\
\text { Giardia lambia. }\end{array}$ & $\begin{array}{l}\text { Amoebic dysentery } \\
\text { Giardians. }\end{array}$ & " \\
\hline $\begin{array}{l}\text { Helminthes } \\
\text { (multicellular } \\
\text { parasites) }\end{array}$ & $\begin{array}{l}\text { Schistosoma sp } \\
\text { (trematodes) (flukes) } \\
\text { fasciola gigantica } \\
\text { taenia sp } \\
\text { Trichuris trichiura } \\
\text { Ascaris (roundworm) } \\
\text { Ancylostoma sp } \\
\text { (hookworm) } \\
\text { Nacator sp }\end{array}$ & $\begin{array}{l}\text { Schistosomiasis } \\
\text { (Bilharziasis) } \\
\text { Fascioliasis } \\
\text { Tapeworm infection } \\
\text { Whipworm nematode infection } \\
\text { Ascariasis } \\
\text { Achylostomiasis (hookworm } \\
\text { infection) } \\
\text { Hookworm infection. }\end{array}$ & $\begin{array}{l}\text { Penetration of infective } \\
\text { stage or direct contact. } \\
\text { Direct contact of } \\
\text { infective stage or } \\
\text { through vector. } \\
\text { " } \\
\text { " } \\
\text { " }\end{array}$ \\
\hline Viruses & $\begin{array}{l}\text { Poliovirus } \\
\text { Adenovirus } \\
\text { Reovirus }\end{array}$ & $\begin{array}{l}\text { Fever, headaches, nausea, } \\
\text { diarrhea, muscular pains, } \\
\text { meningitis, Paralystic polio } \\
\text { Fever, acute upper and lower } \\
\text { respiratory tract infections. } \\
\text { Inflammation of the eyes. } \\
\text { Common cold and other upper } \\
\text { and lower respiratory } \\
\text { tract infections, diarrhea, } \\
\text { hepatitis (especially in children) } \\
\text { Fever, nausea, diarrhea, } \\
\text { hepatitis (acute or chronic). }\end{array}$ & " \\
\hline
\end{tabular}

Source:(12). 


\section{Typical Refuse Dump in a Nigerian Market}

Some of our houses lack appropriate toilet system. Where the modern toilet does not exist, pit latrines are used. Dome of these pit latrines are not properly covered which makes visitation of these vectors possible. Here, flies come in contact with human faeces where they pick these parasites, and thereby act as vehicles for the transmission of the parasites to our fruits, vegetables, food and water. Also, the sachet water hawkers (pure water sellers) could constitute a vehicle of transmission. These sellers especially the children among them have very poor personal hygiene. Some of them are from homes where facilities for washing and faecal disposal are inadequate. Often times, their fingers, body and clothes are dirty and can harbour these parasites and create a conducive environment for the parasites to thrive and be transmitted. Sometimes, market women dispose the faeces of their children in the refuse dump close to their stores in the market.

Flies breed in and feed from refuse dumps where they pick up some parasites. For instance,(13),(14) in their investigations of the parasite burden of some synanthropic flies in Ekpoma, namely Musca domestica, Fannia scalaris, Chrysomya putoria and Ophra leucostoma flies isolated several pathogens including the following parasites, namely Cryptosporidium parvum, Chilomastrix mesnili, Histolytica, Isopora belli, A. lumbricoides, Dicrocoelium hospes, Enterobius vermicularis Hookworm, S. stercoralis and T. Trichiura(15).

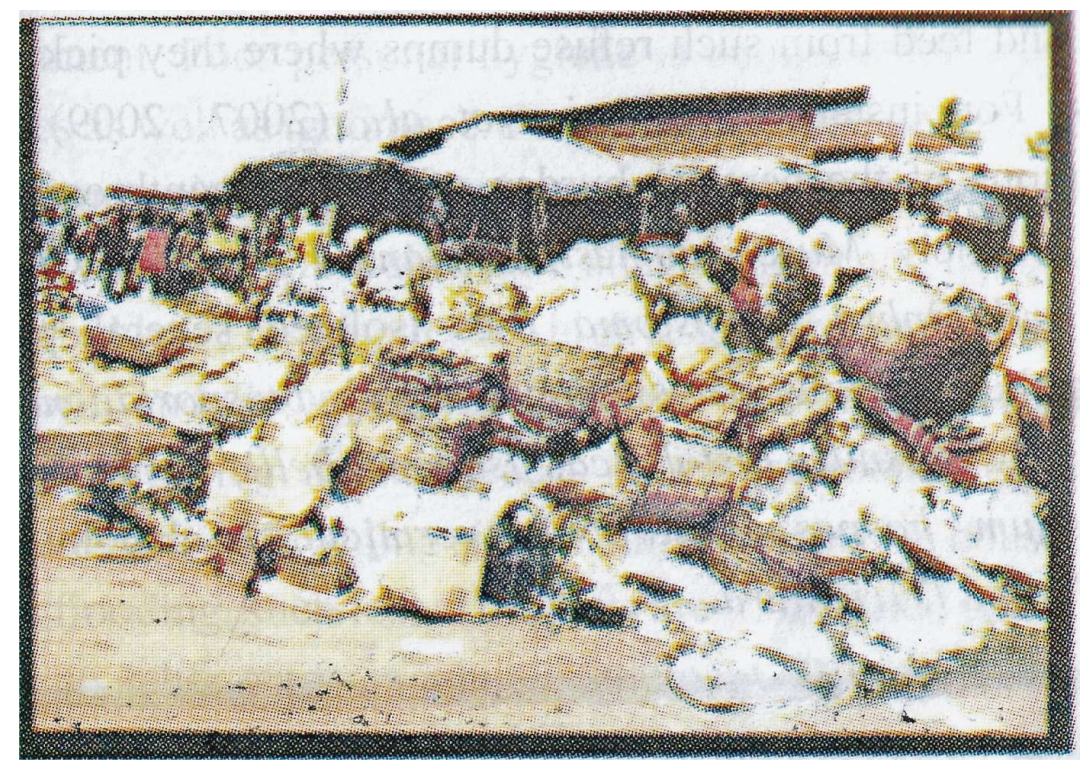

Figure 1: Typical Refuse Dump in a Nigerian Market.

Source:(13)

\section{A Typical Market in Nigeria with Trading Going on Around a Refuse Dump}

Our personal hygiene is another important epidemiological factor in the maintenance of these parasitic infections in our environment. Poor personal hygiene is compounded by our cultural practices as well as ignorance. For instance, some people, especially in Rural Communities take joy in moving about in unprotected feet. Wearing of slippers and shoes are alien to them and in some cases are even forbidden. This practice is a high risk factor for the transmission of hookworm and Strongyloides. Another uninteresting behaviour is a habit of disposing human faeces in our surrounding bushes. 
This constitutes a good breeding site for filth flies such as houseflies. When there is flooding, such faecal droplets are transported from their site of deposit to other areas in our environment. During this process, the ineffective stages of the parasites involved are trapped by farm produce such as fruits and vegetables which are later consumed by people. Some of these parasites are aetiology of some common illnesses such as diaorrhea and Amoebic dysentery. No wonder the prevalence of cases of diaorrhea and Amoebic dysentery in our environment is overwhelming. Also, in institutionalized homes such as hostels where water supply is often inadequate, the act of unsightly or inappropriate defaecation has become the order of the day ${ }^{(15)}$.

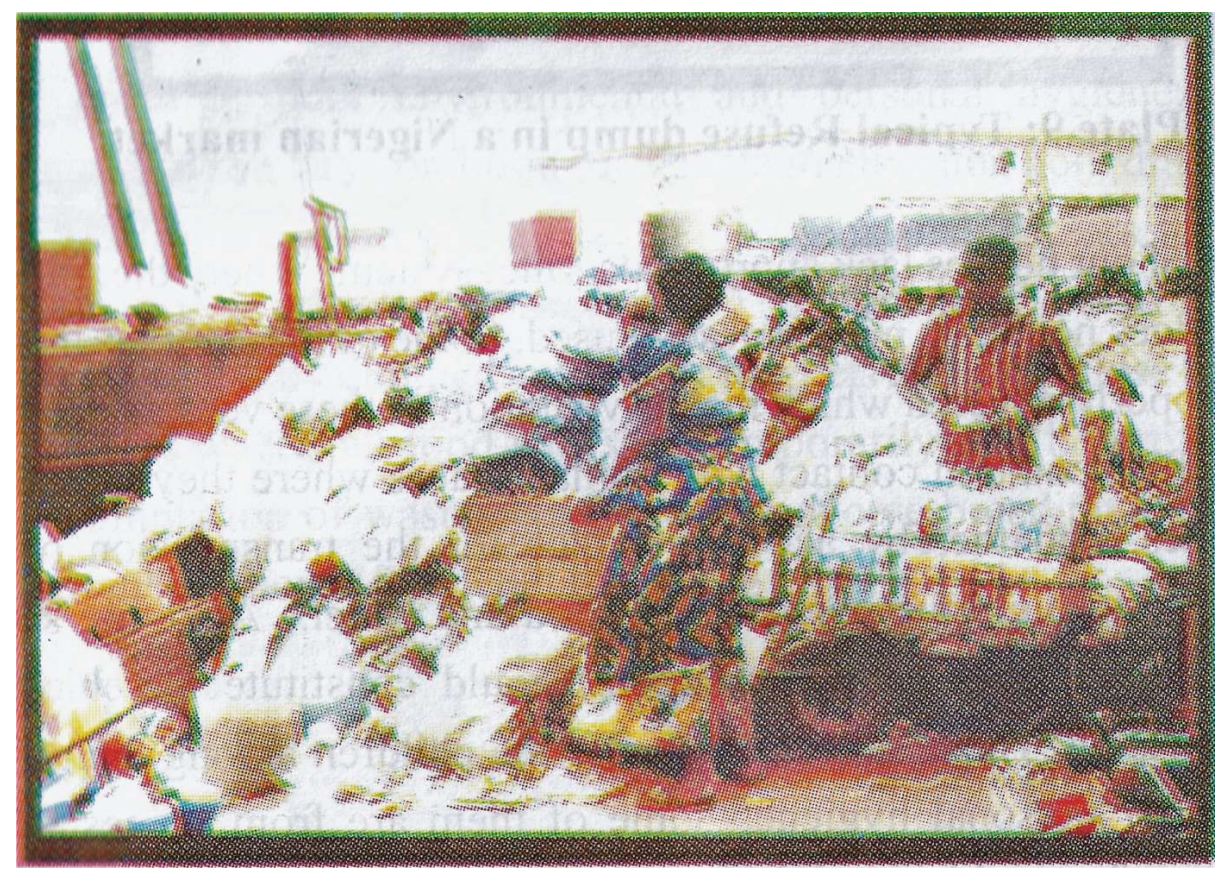

Figure 2: A Typical Market in Nigeria with Trading Going on Around a Refuse Dump. Source:(15). 
Table 2: Examples of Some Chemical Pollutants from Industrial Wastes and Human Diseases Associated with Such Pollutants.

\begin{tabular}{|c|c|c|}
\hline Pollutant & Source of Pollutant & Effects on Humans (Diseases Caused) \\
\hline Sulfur Dioxide & $\begin{array}{l}\text { Combustion of coal, Oil and other Sulfur } \\
\text { containing fuels, petroleum, refining, } \\
\text { metal smelting, paper making. }\end{array}$ & $\begin{array}{l}\text { Swelling in tissues, due to dilation of } \\
\text { blood capillaries, respiratory diseases e.g. } \\
\text { Asthma, Bronchitis, Pulmonary Fibrosis. }\end{array}$ \\
\hline $\begin{array}{l}\text { Particulate } \\
\text { matter in air }\end{array}$ & $\begin{array}{l}\text { Fuel combustion, industrial processes, } \\
\text { construction, forest fires, refuse } \\
\text { incineration, automobile traffic. }\end{array}$ & $\begin{array}{l}\text { Irritations, respiratory diseases and stress } \\
\text { on heart. }\end{array}$ \\
\hline Nitrogen Dioxide & $\begin{array}{l}\text { Produced by combinations of } \\
\text { atmospheric Nitrogen and Oxygen at } \\
\text { high combustion temperatures such as } \\
\text { those in automobile engines, also a bye } \\
\text { product in the manufacturing of } \\
\text { fertilizers. }\end{array}$ & $\begin{array}{l}\text { Cell membrane damage and irritations } \\
\text { causing swelling in the respiratory tract. } \\
\text { Heart stress and diseases. }\end{array}$ \\
\hline $\begin{array}{l}\text { Volatile Organic } \\
\text { Compounds (e.g. } \\
\text { Volatile } \\
\text { Hydrocarbons) }\end{array}$ & $\begin{array}{l}\text { Motor vehicles - evaporation from } \\
\text { gasoline tanks and carburetors industrial } \\
\text { processes involving solvents. }\end{array}$ & $\begin{array}{l}\text { Participation in ozone production. Some } \\
\text { organic compounds are carcinogenic and } \\
\text { can cause cancer. }\end{array}$ \\
\hline $\begin{array}{l}\text { Carbon } \\
\text { Monoxide, } \\
\text { Photochemical } \\
\text { Oxidants }\end{array}$ & $\begin{array}{l}\text { Produced via complex photochemical } \\
\text { reactions in the atmosphere involving } \\
\text { Hydrocarbons, Nitrogen Dioxide, and } \\
\text { Sunlight. }\end{array}$ & $\begin{array}{l}\text { Asphyxiation, heart and brain damage, } \\
\text { poisoning of blood. Pulmonary and heart } \\
\text { stress, fibrosis of lungs and heart failure. }\end{array}$ \\
\hline Hydrogen Sulfide & $\begin{array}{l}\text { Various processes in many kinds of } \\
\text { chemical industries; oil wells, refineries. }\end{array}$ & $\begin{array}{l}\text { Asphyxiation, brain damage, impulses } \\
\text { breakdown. Smell of rotten-egg. }\end{array}$ \\
\hline Fluorides & $\begin{array}{l}\text { Fertilizers manufacture, ceramics } \\
\text { manufacturing, aluminium smelting. }\end{array}$ & $\begin{array}{l}\text { Can combine with non reactive inorganic } \\
\text { and organic compounds, can be } \\
\text { carcinogenic causing cancer. }\end{array}$ \\
\hline Lead & $\begin{array}{l}\text { Combustion of leaded gasoline; solder, } \\
\text { lead containing paint, lead-smelting } \\
\text { operations. }\end{array}$ & $\begin{array}{l}\text { Poisoning (Lead poisoning) can combine } \\
\text { with enzymes rendering them inactive. } \\
\text { Blood destruction and mental } \\
\text { retardations. }\end{array}$ \\
\hline Mercury & $\begin{array}{l}\text { Paper, chemical, paint manufacturing, } \\
\text { pesticides, fungicides. }\end{array}$ & $\begin{array}{l}\text { Poisoning (Mercury poisoning) can } \\
\text { bioaccumulate and cause systemic } \\
\text { poisoning. }\end{array}$ \\
\hline Cigarette fumes & Cigarette smoking. & $\begin{array}{l}\text { Carcinogenic and can cause lung cancer, } \\
\text { even to non-smoker who inhales it. }\end{array}$ \\
\hline Oil / Gasoline & Petroleum products. & $\begin{array}{l}\text { Volatile: some corrosive and highly } \\
\text { inflammable. Can cause Asphyxiation and } \\
\text { suffocation. Also, Carcinogenic and can } \\
\text { cause Cancer. }\end{array}$ \\
\hline
\end{tabular}

Source:(1),(4). 
Table 3: Effects of Chemical Pollutants on Physical Environment and Materials.

\begin{tabular}{|c|c|c|c|}
\hline Chemical & $\begin{array}{l}\text { Primary Material } \\
\text { Attacked }\end{array}$ & Typical Materials Damage & $\begin{array}{l}\text { General Environmental } \\
\text { Effect }\end{array}$ \\
\hline Carbon dioxide & $\begin{array}{l}\text { Building stones e.g. } \\
\text { limestone. }\end{array}$ & Deterioration. & $\begin{array}{l}\text { Contribute to Greenhouse } \\
\text { effects and at the } \\
\text { atmosphere reflects back } \\
\text { all the heat radiation as in } \\
\text { Greenhouse. }\end{array}$ \\
\hline Sulfur oxides & $\begin{array}{l}\text { Metals, Ferrous metals, } \\
\text { Copper } \\
\text { Aluminium } \\
\text { Building materials } \\
\text { (limestone, marble, slate, } \\
\text { mortar, leather) } \\
\text { Paper } \\
\text { Textiles (natural and } \\
\text { synthetic fabrics) }\end{array}$ & $\begin{array}{l}\text { Corrosion } \\
\text { Corrosion to Copper } \\
\text { sulphate (green) } \\
\text { Corrosion to aluminium } \\
\text { sulfate (white) leaching } \\
\text { Weakening } \\
\\
\text { Embrittlement, } \\
\text { disintegration, reduced } \\
\text { tensile strength } \\
\text { Deterioration }\end{array}$ & Contribute to Acid Rain. \\
\hline $\begin{array}{l}\text { Hydrogen } \\
\text { sulfide }\end{array}$ & $\begin{array}{l}\text { Metals (Silver, Copper, } \\
\text { Paint) }\end{array}$ & $\begin{array}{l}\text { Tarnish } \\
\text { Leaded Paint } \\
\text { Blackened due to formation } \\
\text { of Lead sulfide. }\end{array}$ & Contribute to acid rain. \\
\hline Ozone & $\begin{array}{l}\text { Rubber and elastomers } \\
\text { Textiles (Natural and } \\
\text { Synthetic fabric) }\end{array}$ & $\begin{array}{l}\text { Cracking, weakening. } \\
\text { Weakening }\end{array}$ & $\begin{array}{l}\text { Ozone layer depletion in } \\
\text { atmosphere contributes to } \\
\text { global warming and } \\
\text { possibly of skin cancer. }\end{array}$ \\
\hline Nitrogen oxides & Dyes & Fading & \multirow{3}{*}{ Contribute to acid rain. } \\
\hline $\begin{array}{l}\text { Hydrogen } \\
\text { fluoride }\end{array}$ & Glass & Etch marks, opacity. & \\
\hline $\begin{array}{l}\text { Solid } \\
\text { Particulates }\end{array}$ & Building materials & Soiling & \\
\hline Soot, tars & Painted surfaces, Textiles. & $\begin{array}{l}\text { Soiling } \\
\text { Soiling }\end{array}$ & \\
\hline
\end{tabular}

Source:(12). 
Table 4: Summary of PBC Containing Wastes.

\begin{tabular}{|c|c|}
\hline Activity/Courses & Typical Locations \\
\hline $\begin{array}{l}\text { Fluff: waste (upholstery, padding and insulation } \\
\text { materials) derived from the shredding of cars and } \\
\text { appliances. }\end{array}$ & Landfills (municipal and industrial). \\
\hline Inadvertent production by channel plants. & $\begin{array}{l}\text { Industrial waste disposal sites. } \\
\text { Industrial waste water streams. }\end{array}$ \\
\hline Navigational Dredging & Dredged water bodies and their sediments. \\
\hline Transfer Spillage & $\begin{array}{l}\text { Soil or water near landfills and industrial sites and } \\
\text { along the roads between locations. }\end{array}$ \\
\hline Vacuum pump cooling water or condensate. & Water discharges site and leakage. \\
\hline Accident/Fires & $\begin{array}{l}\text { Power distribution (e.g. transformers) industrial sites } \\
\text { material from burnt building. }\end{array}$ \\
\hline $\begin{array}{l}\text { Floor and equipment } \\
\text { Clean-up water }\end{array}$ & $\begin{array}{l}\text { Landfills } \\
\text { Industrials. }\end{array}$ \\
\hline Repair or decommissioning of equipment. & $\begin{array}{l}\text { Repair shop grounds waste disposal sites } \\
\text { Equipment repair or decommissioning sites } \\
\text { Industrial facility grounds. }\end{array}$ \\
\hline Building demolition. & Landfills, waste disposal sites. \\
\hline $\begin{array}{l}\text { Various recycling operations } \\
\text { Reused oil practices. }\end{array}$ & $\begin{array}{l}\text { Recycled oil in equipment } \\
\text { Industrial plants } \\
\text { Pesticide formation } \\
\text { Soft soap formation } \\
\text { Natural gas pipelines (from compressors), } \\
\text { Automobile service stations. }\end{array}$ \\
\hline
\end{tabular}

Source:(12).

Table 5: Classifications of Microorganisms

\begin{tabular}{|l|l|l|l|}
\hline Group & Cell Structure & Characterization & $\begin{array}{l}\text { Representations } \\
\text { Members }\end{array}$ \\
\hline Eucaryotes & $\begin{array}{l}\text { Eucaryotic (contain } \\
\text { time nucleus) }\end{array}$ & $\begin{array}{l}\text { Multicellular with extensive } \\
\text { differentiation of cells and } \\
\text { tissue. Unicellular or coenocytic } \\
\text { of mejalial little or no tissue } \\
\text { differentiation. }\end{array}$ & $\begin{array}{l}\text { Plants (seed plants, } \\
\text { ferrous mosses), Animal } \\
\text { (vertebrates, } \\
\text { invertebrates), Protista } \\
\text { (algae), fungi, protozoa. }\end{array}$ \\
\hline Eubacteria & $\begin{array}{l}\text { Prokaryotic (contain } \\
\text { no nuclear } \\
\text { membrane) }\end{array}$ & $\begin{array}{l}\text { Cell chemistry similar to } \\
\text { eukaryotes. }\end{array}$ & Most bacteria. \\
\hline Archaebacteria & Prokaryotic & Distinctive cell chemistry. & $\begin{array}{l}\text { Methanogens, halophites, } \\
\text { thermacidophiles. }\end{array}$ \\
\hline
\end{tabular}

Source:(1), (4). 
Table 6: Infectious Agents Potentially Present in Raw Domestic Wastewater.

\begin{tabular}{|c|c|c|}
\hline Organisms & Disease & Remark \\
\hline \multicolumn{3}{|l|}{ - Bacteria } \\
\hline $\begin{array}{l}\text { Escherichia coli } \\
\text { (enteropathogenic) }\end{array}$ & Gastroenteritis & Diarrhea. \\
\hline Legionella pneumophila & Legionellosis & Acute respiratory illness. \\
\hline Leptospira (150 spp.) & Leptospirosis & Jaundice, fever (weil's disease). \\
\hline Leptospira typhi & Typhoid fever & $\begin{array}{l}\text { High fever, diarrhea, unleration of small } \\
\text { intestine. }\end{array}$ \\
\hline Salmonella typhi & Typhoid fever & $\begin{array}{l}\text { High fever, diarrhea, unleration of small } \\
\text { intestine. }\end{array}$ \\
\hline Salmonella ( 1700 spp.) & Salmonellosis & Food poisoning. \\
\hline Shigella (4 spp,) & Shigellosis & Bacillary dysentery. \\
\hline Vibrio cholerae & Cholera & $\begin{array}{l}\text { Extremely heavy diarrhea } \\
\text { Dehydration. }\end{array}$ \\
\hline Yersinia enterolitica & Yersinosis & Diarrhea. \\
\hline \multicolumn{3}{|l|}{ - Viruses } \\
\hline Adenovirus (31 types) & Respiratory disease & \\
\hline $\begin{array}{l}\text { Enteroviruses ( } 67 \text { types, e.g. } \\
\text { polio, echo, and Coxsackie } \\
\text { viruses) }\end{array}$ & $\begin{array}{l}\text { Gastroenteritis, heart } \\
\text { anomalies, meningitis }\end{array}$ & \\
\hline Hepatitis A & Infectious hepatitis & Jaundice, fever. \\
\hline Norwalk agent & Gastroenteritis & Vomiting. \\
\hline Reovirus & Gastroenteritis & \\
\hline Rotavirus & Gastroenteritis & \\
\hline \multicolumn{3}{|l|}{ - Protozoa } \\
\hline Balantidium coli & Balantidiasis & Diarrhea, dysentery. \\
\hline Cryptosporidium & Crytosporidiosis & Diarrhea. \\
\hline Entamoeba histolytica & $\begin{array}{l}\text { Amebiasis (amoebic } \\
\text { dysentery) }\end{array}$ & $\begin{array}{l}\text { Prolonged diarrhea with bleeding, abscesses of } \\
\text { the liver and small intestine. }\end{array}$ \\
\hline Glardia lambila & Giardiasis & Mild to severe diarrhea, nausea, indigestion. \\
\hline \multicolumn{3}{|l|}{ - Helminthes } \\
\hline Ascaris lumbricoides & Ascariasis & Roundworm infestation. \\
\hline Enterobius vericularis & Enterobiasis & Pinworm. \\
\hline Fasciola hepatica & Fascioliasos & Sheep liver fluke. \\
\hline Hymenolepis nana & Hymenolepiasis & Dwaft tapeworm. \\
\hline Taenia saginata & Taeniasis & Beef tapeworm. \\
\hline T. solium & Taeniasis & Pork tapeworm. \\
\hline Trichuris trichiura & Trichuriasis & Whipworm. \\
\hline
\end{tabular}

Source:(1), (4). 
Table 7: Specific Organisms that Have been Used or Proposed for Use as Indicators of Human Pollution.

\begin{tabular}{|c|c|}
\hline Indicator of Organisms & Characteristics \\
\hline Coliform Bacteria & $\begin{array}{l}\text { Species of gram-negative rods that may ferment lactose with gas } \\
\text { production (or produce a distinctive colony within } 24 \pm 2 \mathrm{~h} \text { to } 48 \pm 3 \mathrm{~h} \\
\text { incubation on a suitable medium) at } 35 \pm 0.5^{\circ} \mathrm{C} \text {. There are strains that do } \\
\text { not conform to the definition. The total coliform group includes four genera } \\
\text { in the Enterobacteriaceae family. These are Escherichia, Klebiselia, } \\
\text { Citrobactor, and Enterobacter of the group, the Escherichian genus (E. coli } \\
\text { species) appears to be most representative of fecal contamination. }\end{array}$ \\
\hline Fecal Coliform Bacteria & $\begin{array}{l}\text { A fecal coliform bacteria group was established based on the ability to } \\
\text { produce gas (or colonies) at an elevated incubation temperature ( } 44.5 \pm \\
0.2^{\circ} \mathrm{C} \text { for } 24 \pm 2 \mathrm{~h} \text { ). }\end{array}$ \\
\hline Klebisella & $\begin{array}{l}\text { The total coliform population includes the genus klebisella. The } \\
\text { thermotolerant klebisella are also included in the fecal coliform group. This } \\
\text { group is cultured at } 35 \pm 0.5^{\circ} \mathrm{C} \text { for } 24 \pm 2 \mathrm{~h} \text {. }\end{array}$ \\
\hline E. Coli & $\begin{array}{l}\text { The E. coli is one of the coliform bacteria population and is more } \\
\text { representative of fecal sources than other coliform genera. }\end{array}$ \\
\hline Fecal Streptococci & $\begin{array}{l}\text { This group had been used in conjunction with fecal coliforms to determine } \\
\text { the source of recent fecal contamination (man or farm animals). Several } \\
\text { apparently ubiquitous strains cannot be distinguished from the true fecal } \\
\text { streptococci under usual analytical procedures, which detract from their } \\
\text { use as an indicator organism. }\end{array}$ \\
\hline Enterococci & $\begin{array}{l}\text { Two strains of fecal streptococci-S. faecalis and S. faecium - are the most } \\
\text { human-specific members of the fecal streptococcus group. By eliminating } \\
\text { the other strains through the analytical procedures, the two strains known } \\
\text { as enterococci can be isolated and enumerated. The enterococci are } \\
\text { generally found in lower numbers than other indicator organisms, however, } \\
\text { they exhibit better survival in seawater. }\end{array}$ \\
\hline Clostridium Perfringens & $\begin{array}{l}\text { This is a spore-forming anaerobic persistent bacteria, and its characteristic } \\
\text { make it a desirable indicator where disinfections is employed, where } \\
\text { pollution may have occurred in the past, or where the interval before } \\
\text { analysis is protected. }\end{array}$ \\
\hline $\begin{array}{l}\text { P. Aeruginosa and A. } \\
\text { Hydrophila }\end{array}$ & $\begin{array}{l}\text { These organisms may be present in sewage in large numbers. Both can be } \\
\text { considered aquatic organisms and can be recovered in water in the } \\
\text { absence of immediate sources of fecal pollution. }\end{array}$ \\
\hline
\end{tabular}

Source:(1), (4). 
Table 8: Indicator Organisms Used in Establishing Performance Criteria for Various Water Uses.

\begin{tabular}{|l|l|}
\hline Water Use & Indicator Organisms \\
\hline Drinking water & Total coliform \\
\hline Freshwater recreation & Fecal coliform \\
& E. Coli \\
& Enterococci \\
\hline Saltwater recreation & Fecal coliform \\
& Total Coliform \\
& Enterococci \\
\hline Shellfish growing areas & Total coliform \\
& Fecal coliform \\
\hline Agricultural Irrigation & Total coliform \\
& (for reclaimed water) \\
\hline Wastewater effluent disinfection & Total coliform \\
& Fecal coliform \\
\hline
\end{tabular}

Source:(1), (4).

\section{PREVENTION AND CONTROL/MANAGEMENT OF WASTE}

Refuse:

(i) Indiscriminate dumping of refuse should be avoided and no dumping into gutters or public places.

(ii) Reduction in generation of the waste. Some items that can be reused or recycled should be reused to reduce throw away habit.

(iii) When disposed in small quantities regularly as they are generated, the health implications are also solved.

(iv) If the items should be thrown away, they should be put into proper bins and transported in the proper vehicle for proper disposal. This should be done promptly on daily basis i.e. refuse must not be allowed to accumulate for a long time as to form heaps and areas where vectors fested and parasites and pathogens thrive.

\section{Sewage:}

(v) Proper disposal of faeces and sewage into modern day toilets with water closets into well-covered septic tanks is necessary. Alternatively, faeces and sewage should be disposed in proper pit latrines that are well ventilated and the hole properly covered to prevent vector access to the faeces.

(vi) Proper personal hygiene is also very necessary.

\section{Commercial Wastes}

(vii) Some commercial wastes can be recycled. This should be encouraged. Just like refuse, the commercial wastes generation should be reduced. Items should not be abandoned but made utilizable. General environmental sanitation should be fully supported and encouraged. 


\section{Agricultural Wastes}

(viii) Proper handling and processing of agricultural products. Some agricultural wastes are reusable, this should be explored and utilized e.g. poultry droppings as fish feeds.

\section{Industrial Wastes}

(ix) Great efforts should be made to treat the effluents before being thrown into the environment.

(x) The FME guideline on minimum acceptable limits of the effluent in the environment should be strictly adhered to. Generally, there should be environmental education to enlighten people on responsibilities to the environment for good health.

(xi) Enforcement of environmental laws should be intensified to make people comply with the rules for public health. There should be good sanitation and people should develop good sanitary culture and living habits to avoid all forms of environmental diseases.

\section{CONCLUSION}

3. Nature has a capacity of healing herself. The air, water and soil all have amazing capacities to heal themselves. However, the scientific world should not leave any room for complacency because natural processes can be overloaded if the rate of residue depositions and transport is exceedingly high. How well we adapt to our environment depends on how well we understand how it works. Keeping the society in darkness as regards environmental issues is denying it of the powers to deal with the environment for better standards of living. Environmental laws like all laws reflect the idea of a legislative class on how we ought to live our life. The Nigerian legal order is reflective on the activities of Nigerians in Nigeria. legislation against the abuses of environment is not an easy task. More so, for a developing capitalist economy, the criminal nature of protection of the environment puts the responsibility of prosecution in the government(16).

4. It is important to note that once one place is filthy on the environment, and adequate attention is not directed to it, there could be outbreak of any disease and can affect anybody in that environment. Therefore Individuals, Communities, Government NGOs should play their roles towards the [proper management of wastes. People should always make environment clean, just as the saying goes "Cleanliness is next to Godliness". Segregation of wastes according to types and decomposition rates in the case of refuse should be practiced(12).

5. Increase in population will lead to the destruction of land, depletion of natural resources, increasing greenhouse gas emissions, ozone depletion, acid rain, and production of wastes and other forms of pollution. Environmental pollution has now becomes an issue of international politics; it will be cominant on the international agenda for as long as man lives. The world should, therefore, realize that a threat to the environment is a threat to National or Global Security(2).

6. Some developing Countries appear to trivialize environmental issues. Fortunately, Nigeria has a well defined National Policy on the Environment, whose goal is to achieve sustainable development in the Country. Within the context of the United Nations Agenda 21, Sustainable Development is "Development that meets the needs of the present without compromising the ability of the future generations to meet their own needs. The creation of the Ministry of Environment by the Federal Government, and the Inauguration of a Committee on Environment by the Federal House of Representatives, are indicative of Nigeria's renewed commitment to environmental protection and sustainable development. 
7. As societies grow richer through advanced technology, their environments grow poorer. This inverse relationship between societal wealth and environmental poverty cannot nurture sustainable development.

8. The protection of people who now choose to purchase a product because of its environmental friendliness is increasing, while eco-labelling of manufactured products is gaining ground in the developed Countries. Nigeria should incline without delay to this level of environmental consciousness.

9. Nigeria's real environmental consciousness, no doubt, was aroused in 1988 when 12 Nigerian students in Italy informed us that toxic industrial wastes were being shipped from Italy to this Country. These 12 Nigerians (if not yet honoured) should be honoured by Nigeria for their unalloyed patriotism. In fact, the promulgation of the Federal Environmental Protection Agency Decree No. 58 o 1988 was as a result of the environmental consciousness used in this country by these Italy-based Nigerians.

10. The Nigerian government should be commended for establishing FEPA now federal Ministry of Environment. However, Federal Ministry of Environment (FMENV) requires not only legal teeth, but also, adequate funds to be able to function satisfactorily and effectively(2).

11. There is need for FMENV to have More Town Crier's Division (MTCD), in each State, Local Government and Ward charged with the responsibility of educating the Nigerian populace on the evils of environmental pollution and degradation. This division should be well equipped for effective and mission-oriented operations: films on environmental pollution and degradation should be shown in hamlets, villages and towns. Also, public enlightenment lectures should be given to Nigerians in English or vernacular as the case may be.

12. The National Protection (Effluent Limitation) Regulations of $15^{\text {th }}$ August, 1991; the National Environmental Protection (Pollution and Abatement in Industries and Facilities Generating Wastes) Regulation of 15th August, 1991; the National Environmental Protection (Management of Solid and Hazardous Wastes) Regulations of 30th December, 1991; and, Environmental Impact Assessment Decree No. 86 of $10^{\text {th }}$ December, 1992, should be strictly enforced in the interest of Nigeria's sustainable development.

13. Sustainable development, as it is now widely acceptable, depends on women; it is also widely accepted that women play the larger role in Grassroots Environmental Protection. Nigeria women should therefore, be seen to be involved in both planning and execution of Nigeria's environmental policies.

14. Environmental education should be compulsory at the Primary and Secondary Levels in this Country while at the Tertiary Level, more topics on the environment should, as a matter of course, be incorporated into the General Studies Programmes and Curriculum.

15. The Niger-Delta should be declared a disaster region ${ }^{(17)}$. The call was made to draw the attention of government as well as that of the pro-environment Non-Governmental Organizations (NGOs) and public spirited individuals, to the plight of the Niger-Delta, with a view to ameliorating its deplorable environmental conditions. The call fell on deaf ears or had no ears to fall on. Thus, the situation of the region deteriorated day by day, to the extent that living in the area is now tantamount to plunging oneself into insecurity, uncertainty and regression. The misery arising from the impoverishment of the region, its unhealthy living condition and dwindling economic activity daily adorn our dailies. The picture often painted of the Niger-Delta is that of a region whose inhabitants are fast constituting a clan of the wretched of the earth. I wish to say and stress for the umpteenth time that the Niger-Delta should be declared a disaster region(2). 
16. Industries in the Niger-Delta should ensure that environmental protection has equal priority with profitability. Clean, environment-friendly technology should be used in the exploration and production of gas and Oil in the region.

17. Nigeria should wage a full-scale war against ignorance and superstition to make her citizens appreciate the gravity and lethal consequences of environmental pollution and degradation. Listen to what the oldest man in Koko said by way of reacting to government's call for the evacuation of Koko residents immediately after the discovery of toxic wastes in the village: "If we move, what becomes of the graves of our ancestors?"(18). The revered old man, of course, had the legitimate right to be sentimentally and culturally attached to his home and land of his ancestors, but if he were from a society that has imbibed science culture and environmental awareness, he would have, first of all, considered his own health, the health of his fellow villagers, and the impending danger which the future generations might face.

18. Out of sheer greed and ignorance (perhaps, more of the latter), some inhabitants of the Niger-Delta have resorted to the cutting of flow lines and tampering with the facilities of the Oil Companies operating in the area. This act of sabotage leads to Oil spillage and gas leaks. The saboteurs engage in this unholy practice to enrich themselves or to "punish" the Oil Companies as a way to compel them to pay compensation to the Oil-Producing Communities. The consequences of such act of sabotage are unimaginable, as the damage it does to the environment is beyond compensation. All acts of sabotage deserve condemnation as the adverse consequences of such acts are immeasurable.

19. The sources of drinking water and the farmlands of the Oil-Producing Communities in the Niger-Delta are very badly polluted and poisoned by industrial activities. Such Communities MUST be adequately compensated in such a way that even future generations can benefit from such compensation. However, I personally believe that the best thing really is the prevention of industrial pollution. What, after all, is the use of compensation for a Community whose future generations may be limbless. Blind, sterile and mentally retarded? What is the use of compensation for a Community whose average life span may be considerably shortened as a result of environmental pollution? Let me say it loud and clear once again that prevention is better than compensation. In fact, the rates of still-births and caesarian sections in the Niger-Delta appear to be high; the sperm counts in the area are "low compared to the general public" as reported by Doctors for all Nations.

20. The social environmental problems of the Niger-Delta are as a result of political and economic mistrust among the ethnic groups of the Oil-Producing Areas. Fierce intra-ethnic clashes all over the Niger Delta Areas leading to loss of lives, as in the case of Benekuku and Umasadege people in Ndokwa land over the ownership of the parcel of land, where Oil in large commercial quantity, has been discovered, are common in the Niger-Delta. Inter-ethnic conflicts all over the Niger Delta Areas resulting in the death of thousands of people, as in the case of the Itsekiris and the ljaws or the Urhobos are also commonplace. The neglect of the Oil-producing Communities have often angered them resulting in their Militant Youths venting their anger on Staff and installations of Oil Companies. All these acts further contribute to the pollution and degradation of the Niger-Delta. The need for the Oil Companies and the Oil Producing Communities to be yoked together cannot be over-emphasized. As Stakeholders, they should see themselves as partners in progress. Indigenes of the Niger-Delta should live in harmony with one another, as no meaningful, sustainable development can take place in the region without peace. The need for honest, selfless Community leadership endowed with integrity and vision has now become imperative. The fight against deprivation, colonization, marginalization, expropriation and other forms of injustice in the Niger-Delta can only be won when fought collectively with unanimity. We should learn to live as one happy family. The present posture 


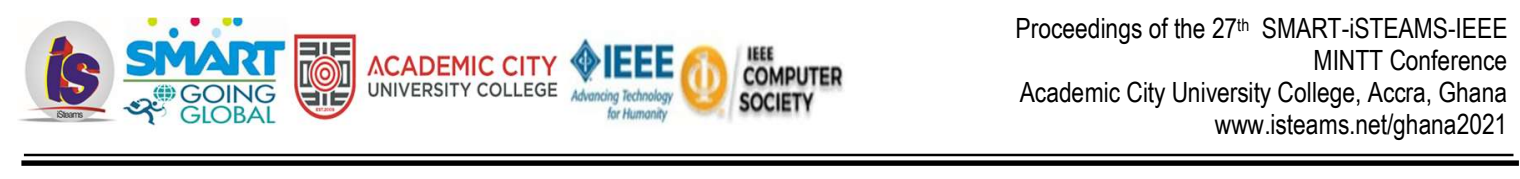

in the area, synonymous with a discordant note, will lead the Niger-Delta nowhere in its struggle for self-determination. The Niger-Delta Development Commission should collaborate with other NigerDelta Environmental Stakeholders to avoid wasteful duplication of all efforts. Nomadic Schools have been established for children of monads in some parts of Nigeria. Similar schools should be built for the children of migrant fishermen of the Niger-Delta region. Personally, I see the migration of fishermen from one location to another as a type of nomadism - riverine nomadism.

21. The Nigerian government should, without any further delay, pursue a policy of near-complete indigenization of the Oil industry. More Nigerians should be adequately trained and exposed to the state-of-the-art in Oil technology to enable them man it in due course in Nigeria's Oil Industry.

22. There is so much to gain from the survival of wild species in the Niger-Delta. Protected areas should be established in the region to prevent further loss of biodiversity.

A frantic appeal is being made to humanity to live in harmony with one another. Our goal is to make the world a healthy place to dwell. The emphasis of the global family should therefore, be on sustainable development. We should always realize that if man does not put an end to environmental pollution, pollution may put an end to man. Environmental pollution is all gloom, no glee - it brings no good news to humanity. As we strive to live in a healthy environment, we should also ensure through conscious environmental conservation that our children and our children's children live in a healthier world, full of hope and harmony ${ }^{(19)}$.

\section{REFERENCES}

(1) Idehen, K.I. (2002), eds. In Ogodo, A.D. and Idehen, Q.O. (2006c), The Need for Harmonization, Effective Enforcement and Implementation of Existing Environmental Laws and Guidelines on Waste Management Problems in Nigeria: The Future Direction. Chemech Journal, An Official Publication of the Chemical Society of Nigeria, Edo State Chapter. 2: 387-399.

(2) Okecha, S.A. (1999), Environmental Pollution: All Gloom, No Glee. Public Lecture Delivered at the Seventh Edition of the Delta State Public Service Forum, $3^{\text {rd }}$ August. Unity Hall, Government House, Asaba, Delta State, Nigeria. Graduate School, Edo State University, Ekpoma, Nigeria.

(3) Asiodu, P.C. (1995), "Towards Sustainable Development in Nigeria". Keynote Address at the World Environmental Day, Lagos $-5^{\text {th }}$ June.

(4) Ogodo, A.D. (2012), Environmental Pollution, Degradation, Legislations and its Effects on Human Health in the Niger-Delta Region of Nigeria. Journal of Nigerian Environmental Society (JNES), Vol. 7, No. 2, PP. 97-106.

(5) Ola, C.S. (1984), Town and Country Planning and Environmental Laws in Nigeria. 3nd Edition, University Press Limited, Ibadan.

(6) Mokwenye, Ikebu I. (2005), Environmental Challenges for Sustaining the Niger Delta Area (Case Study: The Effect of Petroleum Industries in Warri and Environs), August 2005. Petroleum Training Institute, Effurun, Near Warri, Delta State, Nigeria. Nigerian Environmental Society Monthly Technical Report (NES), Delta State Chapter.

(7) The Environmental Outreach (2014), House of Representatives, Stakeholders Hold Industries, Firms Responsible for Poor Solid Waste Management. The Environment Outreach, Nigeria's Number 1 Environmental and Development Newsmagazine, Volume 2, Number 14, July - September 2014. Page 24. 
(8) Ogodo, A.D., Odebala, J.Y., Omovie, D.O. and Ataikiru, H. (2006c), Environmental Legislation and Enforcement: Towards the Search and Need for Constitutional Reforms, Harmonization, Effective Enforcement and Implementation of Existing Environmental Laws on Waste Management Issues in Nigeria. Journal of Nigerian Environmental Society (JNES), 3 (1 and 2): Pages 1-22.

(9) Ukoli, F.M.A. (1992), Prevention and Control of Parasitic Diseases in Tropical Africa (The Main Issues). University Press Plc., Ibadan.

(10) Okecha, S.A. (1995), "Environmental Pollution: The Scourge of Lifekind". Public Lecture, Federal University of Technology, Owerri, Nigeria, $31^{\text {st }}$ May.

(11) P.T.I. (1998), Pollution Prevention and Control: A Short Course. Petroleum Training Institute, Effurun, Near Warri, Delta State, August.

(12) Eremiokhale, J.I. \& Ahianba, J.E. (2005), Environmental Pollution and Health Hazard: The Case of Etsako Land in Edo State. Conference on Building and Environmental Development in a Depressed Economy, 25th $-27^{\text {th }}$ October 2005. The New Auditorium, Auchi Polytechnic, Auchi, Edo State, Nigeria.

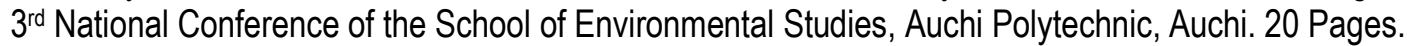

(13) Nmorsi, O.P.G., Ukwandu, N.C.D. and Agbozele, G.E. (2006), Detection of Some Gastro Intestinal Parasites from Four Synanthropic Flies in Ekpoma, Nigeria. Journal of Vector Borne Diseases (43): 136-139.

(14) Nmorsi, O.P.G., Isaac, C., Ukwandu, N.C.D., Ekundayo, A.O. and Ekoziem, M.I. (2009), Schistosoma haematobium and Plasmodium falciparum Co-infection with Protection against Plasmodium falciparum Malaria in Nigerian Children. Asia Pacific Journal odf Tropical Medicine, 2(2):16-20.

(15) Nmorsi, O.P.G. (2013), The Impact of Some Parasitic Infections on Longevity of Man. $46^{\text {th }}$ Inaugural Lecture of Ambrose Alli University, Ekpoma, Nigeria, Thursday, April 25. 70 Pages. Published by Ambrose Alli University Publishing House, Ekpoma, Nigeria. Printed by PDN Publishers Limited.

(16) llogho, T.U. (2005), Critical Examination of Enforcement of Environmental Laws in Nigeria. Conference on "Building and Environmental Development in a Depressed Economy, 25th $27^{\text {th }}$ October 2005. The New Auditorium, Auchi Polytechnic, Auchi, Edo State, Nigeria. $3^{\text {rd }}$ National Conference of the School of Environmental Studies, Auchi Polytechnic, Auchi. 15 Pages.

(17) Okecha, S.A. (1996), Environmental Pollution: The Bane of the Oil-Producing Areas Lecture Delivered at the 1996 Annual Lunch of the Nigerian Medical Association, Isoko/Ndokwa Chapter, Jahrose Hotel, Kwale. $1^{\text {st }}$ March.

(18) Newswatch Magazine (1989), Lagos, $4^{\text {th }}$ July. P. 15. 